\title{
Positive experience of full-layer filling of articular cartilage defect using a degradable implant with a bioactive surface in combination with platelet-rich blood plasma (experimental study)
}

\author{
A.V. Popkov, D.A. Popkov, A.E. Kobyzev, E.N. Gorbach, N.A. Kononovich, E.S. Gorbach \\ Ilizarov National Medical Research Centre for Traumatology and Orthopedics, Kurgan, Russian Federation
}

\begin{abstract}
Defects of the cartilage surface are a frequent joint damage in orthopaedic practice. First of all, they arise as a result of highenergy trauma or a consequence of chronic systemic diseases. In both cases, incongruence of the articular surfaces leads to the development of osteoarthritis. Joint resistance to residual incongruence depends on the depth and area of the damage, as well as on the thickness of the articular cartilage. The restoration of cartilage defects in the knee joint remains one of the urgent problems of modern orthopedics and traumatology. Purpose Search for new methods for filling extensive defects of the articular cartilage of joint surfaces with the possibility of restoring a typical joint structure. Materials and methods Using clinical, microanatomical, and histological methods, a study was conducted to investigate the possibility of filling the defect of the joint surface of the femoral condyles of adult mongrel dogs $(n=3)$ with a thin elastic polycaprolactone woven by electrospinning, the threads of which are coated with hydroxyapatite nanoparticles, in combination with the introduction of an enriched platelet blood autoplasma into the defect. Results After 60 days of the experiment, restoration of the congruence of the articular surface along with mosaic-like replacement of the implanted material in the region of the cartilaginous layer with portions of hyaline-like cartilage and in the subchondral bone zone with a new cancellous bone tissue was noted. In the defect of the articular surface of the control animals, which was not filled with a bioactive implant, vascularized loose fibrous connective tissue was formed after 60 days of the experiment. Conclusion The results obtained may be promising in terms of the possibility of prolonging the functional ability of joints in patients with articular cartilage defects; after further longer experimental and clinical observations) may offer a new universal method for filling articular defects of various etiologies to restore their biomechanics and typical strudcture.
\end{abstract}

Keywords: articular cartilage defect, experiment, graft, polycaprolactone, hydroxyapatite, reparative regeneration, transosseous osteosynthesis

\section{INTRODUCTION}

Defects of the cartilage surface are a frequent joint damage in orthopaedic practice. First of all, they arise as a result of high-energy trauma or a consequence of chronic systemic diseases. In both cases, incongruence of the articular surfaces leads to the development of osteoarthritis. Joint resistance to residual incongruence depends on the depth and area of damage, as well as on the thickness of the articular cartilage. The restoration of cartilage defects in the knee joint remains one of the urgent problems of modern orthopedics and traumatology. [1, 2, 3, 4].

The whole variety of surgical interventions in order to manage the defects in the articular cartilage can be divided into several directions:

a) Defect treatment to stimulate spontaneous regeneration associated with tunneling, perforation, or microfracturing of the subchondral bone plate $[5,6,7]$;

b) Filling the defects with autologous material from bone, periosteum, chondroid and stem mesenchymal cells $[8,9,10,11]$;

c) Plasty of cartilage defects with artificial implants $[12,13,14]$.
The complexity of surgical treatment of articular cartilage defects is associated with low reparative ability due to the lack of direct blood supply to the cartilage and its structural features [15]. The avascular nature of the cartilage prevents the development of the inflammatory phase and the migration of stem cells into it, and the dense extracellular matrix forms a physical barrier to migration of existing chondrocytes into the defect $[15,16,17,18]$.

Techniques of abrasive plasty, tunneling, and microfracturing of the defect bottom have been known. They have various terms: "subchondral stimulation", "osteoperforation", "bone marrow stimulation" [19, 20, 21]. The mechanism of action of these methods is based on the exit for bone marrow mesenchymal stem cells into the defect zone. The latter ensure the formation of fibrous cartilage cells in the defect zone [22].

The fibrous cartilage that fills the defect is inferior to hyaline cartilage in its mechanical properties. Moreover, the defect is not always filled completely. The results of the treatment of patients with cartilage defects by microfracturing have been published a lot [6, 22, 23, 24].

Popkov A.V., Popkov D.A., Kobyzev A.E., Gorbach E.N., Kononovich N.A., Gorbach E.S. Positive experience of full-layer filling of articular cartilage defect using a degradable implant with a bioactive surface in combination with platelet-rich blood plasma (experimental study). Genij Ortopedii, 2020, vol. 26, no 3, pp. 392-397. DOI 10.18019/1028-4427-2020-26-3-392-397 
The analysis of these works indicates that, despite the simplicity of the proposed approaches to the application of this method, it is difficult to predict the results of treatment [25]. There is still no answer to the question about the defect area to obtain a guaranteed positive outcome of such surgical treatment.

Among the second-line technologies, the technique most often used in the clinic is the mosaic plasty of cartilage defects. Developed about 20 years ago, it offered promising prospects [26]. However, as it turned out, its therapeutic range is not wide enough. It is the area of the cartilage defect which can be filled using this method under question. Clinical observations have shown that the filling of the defects in which four or more cylinders are transplanted is very traumatic due to a large volume of the donor zone. Most of the orthopaedic surgeons operating with the method have come to the conclusion that mosaic repair is most effective when a small amount of cylinders is transplanted, maximum three and with an average area not exceeding $1.5 \mathrm{~cm}[25,26,27,28]$. Large cartilage defects may be filled by autologous chondrocyte transplantation. Autologous chondrocyte transplantation is a two-stage operation, including arthroscopy with the extraction of a healthy cartilage portion from which an autologous chondrocyte culture is grown. At the second stage, this culture of chondrocytes is implanted into a cartilage defect under a patch from an autologous periosteum [29, 30]. The main disadvantages of the technique are the high cost, two-stages of the surgical intervention, and the need for arthrotomy. In addition, studies on long-term results of transplantation of autologous chondrocytes showed that they do not always differ significantly from the results of microfracturing, which was performed for the same size of cartilage defects. Ossification of the newly formed layer is also possible [31, 32].

The aim of this study was to search for new methods of managing extensive defects in the articular cartilage of articulating surfaces with the possibility of restoring their typical structure.

Research objectives Using clinical, anatomical and histological research methods, to study the possibility of filling the joint surface defect of canine femoral condyles with an elastic hydroxyapatitecoated biodegradable polycaprolactone implant combined with the introduction of a platelet-rich blood plasma into the defect.

\section{MATERIAL AND METHODS}

This experimental study is based on the concept that the advancement of implantation in modern conditions for treatment of articular surface defects should be based on the development of implants, taking into account the anatomical features of the articulating surfaces, regardless of the shape and size of the defect formed. A thin (100-300 $\mu \mathrm{m})$, very flexible, degradable implant, woven by polycaprolactone electrospinning, the threads of which are coated with hydroxyapatite nanoparticles (Fig. 1) is proposed.

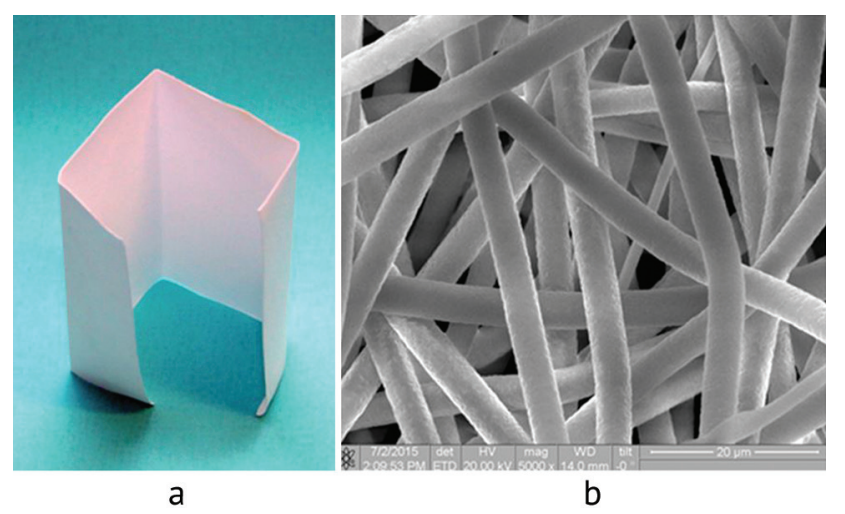

Fig. 1 Photo (a) and electron pattern of a polycaprolactone implant (b) woven by electrospinning (magnification $5000 \times$, threads coated with hydroxyapatite nanoparticles are visible)

Dogs of both sexes $(n=3)$ aged from one year to 3 years with a body weight of $20 \pm 2.9 \mathrm{~kg}$ were used in the experiment to study the biological characteristics of articular cartilage regeneration. Under general anesthesia, a defect on the articular surface of the femur was prepared down to the level of a viable subchondral bone using a cylindrical cutter with a diameter of $10 \mathrm{~mm}$. At the edges of the defect, a thin chisel was used to detach articular cartilage from the subchondral bone to a depth of 1-2 $\mathrm{mm}$. The edges of a thin superelastic polycaprolactone implant were fixed in this subchondral fissure. Blood plasma, enriched with platelet-derived growth factors prepared before surgery from the same animal (platelet-rich PRP) [33, 34, 35], was injected under the embedded implant.

Blood $(8 \mathrm{ml})$ was taken from animal's vein into tubes for plasmolifting. Single centrifugation was carried out for 5 minutes at 2.5 thousand revolutions per minute. PRP contained at least one million platelets per $1 \mathrm{ml}$ of plasma (the platelet content in PRP exceeded the physiological norm by 5 times).

After the surgery, the joint was fixed with an external fixation device in a functional position for one month and then the fixator was dismantled.

For comparison, the same defect of the articular surface of the femur was formed, but implantation and stimulation of chondrogenesis was not applied in the control animals $(n=3)$.

After the intervention, cefazolin was administered intramuscularly for 7 days ( $0.5 \mathrm{~g}$. 2 times a day). Wounds were monitored daily. 
Dogs were euthanized with an overdose of barbiturates 30 days after removal of the fixator (on the 60th day of the experiment).

The process of articular surface defect filling was studied on anatomical preparations of the limb, and chondrogenesis was checked with morphological methods. After anatomical description, an area of a full-layer defect of the articular surface filled with tissue detritus was excised with the capture of intact tissues. The sawn block was divided into two halves. One was fixed in a $10 \%$ solution of neutral formalin, decalcified in solutions of hydrochloric and formic acids, dehydrated in ascending alcohols, and embedded in paraffin. Histological paraffin sections were prepared using a sledge microtome (Riechard, Germany) and stained with hematoxylin and eosin according to Masson. The second half of the block was divided into cylindrical fragments with a side of $2-3 \mathrm{~mm}$ and a height equal to the depth of the defect formed, fixed in a mixture of aldehyde fixers with picric acid and poured into epoxy resins. Semi-thin sections with a thickness of 1-2 $\mu \mathrm{m}$ were prepared from non-decalcified material using the LKB Bromma Ultratome Nova ultratome and diamond knives and stained with methylene blue with preliminary setting of the PAS reaction. Descriptive light microscopy study was performed using an AxioScope. A1 stereo microscope and an AxioCam ICc 5 digital camera, complete with Zen blue software (Carl Zeiss MicroImaging $\mathrm{GmbH}$, Germany).

The experiments were carried out in accordance with the requirements of the European Convention for the Protection of Vertebrate Animals Used for Experimental and Other Scientific Purposes (Strasbourg, 1986) and were approved by the local Ethics Committee.

\section{RESULTS}

In the early postoperative period, the condition of the animals was satisfactory. They independently moved with full support on the operated limb despite the external fixator. No infectious complications were observed; and all postoperative wounds healed by primary intention. Animals had a good appetite and did not reduce body weight. After joint fixation completed (dismantling the external fixation apparatus) the range of active and passive movements in the joint quickly restored. Experimental studies showed that the use of implants did not cause any immunomorphological hypersensitivity of the immediate type. Remodelling resulted in joint surface defect filling with bone and cartilage tissues.

Two months after filling the full-layer defect of the articular surface with an elastic implant material from polycaprolactone and introducing platelet-rich blood plasma, an even shiny continuous layer of transparent whitish cartilaginous tissue with a surface structure similar to the edges of the intact articular cartilage was observed on the defect surface at the macrolevel (Fig. 2).

The transparent surface formed enabled to clearly visualize the subchondral bone and microvessels in its structure, which did not penetrate into the similar to cartilage outer covering of the defect, but even more transparent. The congruence of the articular surface was restored. There were no signs of inflammation. The synovial fluid was clear, similar to that in the intact joint. Its volume was sufficient.

Histological studies showed that the organization of the regenerate in the area of a full-layer defect on the articular surface of the dog's bone was different in different parts of the forming matrix (Fig. 3).

In the projection of the subchondral bone, bone matrix featuring trabeculae of both reticulofibrotic and lamellar bone tissue was formed (Fig. 3 a), and closer to the level of the articular surface, the formation of extensive portions of a hyaline-like matrix in which chondroblast-like cells surrounded by a homogeneous intercellular matrix were found (Fig. 3 b).

During the study, fragments of biodegradable implantation material were also found in the regenerate zone, in the vicinity of which giant cells of foreign bodies and cells of a monocytic-macrophage type were observed.

In the control defect of the articular surface, which was not filled with a bioactive implant, a vascularized loose fibrous connective tissue was formed (Fig. 3 c).

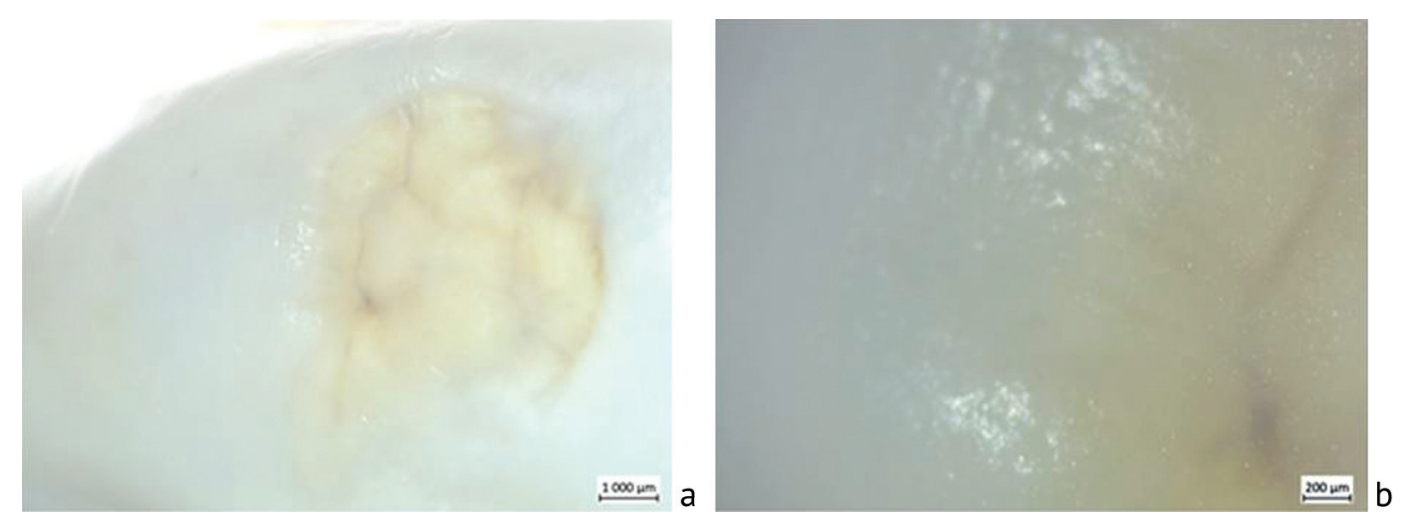

Fig. 2 Macrophoto of the defect in the experimental group two months after the defect has been filled ( $a$ - magnification $10 \times$; $b$ - magnification $20 \times$ ) 

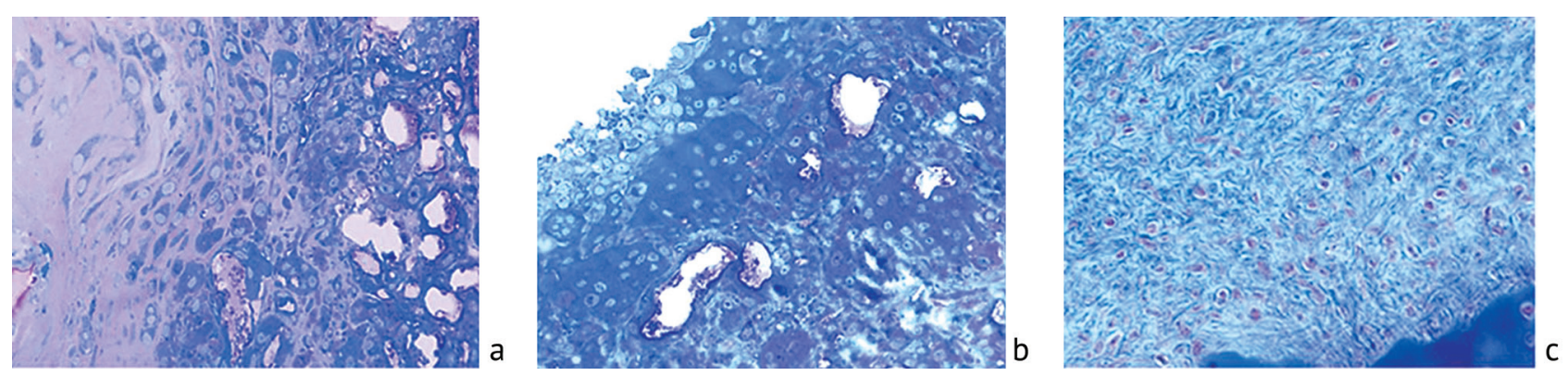

Fig. 3 The histostructural organization of the regenerate in the area of the full-layer defect of the articular surface of the dog's bone two months after the operation: $a$ - formation of the bone matrix in the projection of the subchondral bone; $b$ - formation of the portions of a hyaline-like matrix (white rounded formations are the remains of a degraded implant); $c$ - a control defect of the articular surface is presented for comparison, which was not filled with a bioactive implant (a fragment of loose fibrous connective tissue); staining with methylene blue with preliminary setting of the PAS reaction. Magnification, $400 \times$

\section{DISCUSSION}

This study has demonstrated that the potential for regenerative restoration of hyaline cartilage is very real. After two months, the implanted material was mostly replaced by a tissue matrix. The histological picture revealed indicates the prospect of further biodegradation of the remaining fibers of the implantation material and the possibility of acquiring the organotypic structure of the newly formed portion of the cartilage surface in the region of the defect.

'In our opinion, the use of a bioactive mesh implant from caprolactone with the inclusion of hydroxyapatite promotes adhesion of progenitor cells, osseointegration and chondrointegration of the implant. A defect in the articular surface is quickly filled by the formed matrix, and the articulating surface does not impair the congruence of the joint.

The bone marrow in the subchondral space has sufficient osteogenic and chondrogenic potential, being a source of undifferentiated progenitor cells of osteoblasts, osteoclasts, fibro- and chondroblasts migrating to the defect area.

The mesh implant allows free circulation of biological fluids penetrating into it both from the side of the subchondral bone and from the side of the joint cavity, which stimulate proliferation, differentiation, and biosynthetic activity of cells both in the projection of cartilage tissue regeneration and in the subchondral bone area. This effect, in our opinion, is ensured by the fact that the implant itself performs not only the role of a matrix for the adhesion of poorly differentiated cells, but also the role of a kind of boundary membrane with the function of a biological sieve at the initial stages of regeneration until biodegradation of the implant material. It prevents the growth of vessels from the subchondral bone and calcification of the forming cartilage regenerate, but does not prevent the migration of poorly differentiated cells. This is facilitated by the size of the pores or interfiber spaces (not more than 1215 microns), which ensure the penetration of nutrient and biologically active liquids (additionally introduced platelet-rich blood plasma) and poorly differentiated cells, but not the ingrowth of microvessels. Then, the gradual biodegradation of the implant increases the interfiber spaces in its structure and does not prevent the blood vessels from growing into it from the periphery and the bone bottom of the defect, while a dense tissue matrix is already formed on the side of the cartilaginous defect, restricting their penetration into the area of the forming cartilage lining.

Subchondral bone is formed round the capillaries, represented by trabeculae of the reticulofibrotic structure, over which the cells of hyaline cartilage differentiate. An implant located in the cartilage defect fully integrates with bone and cartilage and quickly degrades; the joint surface becomes solid, smooth, shiny and functionally identical to an anatomically healthy joint.

The cell effect is enhanced by the use of platelet-rich plasma (PRP), which contains at least 1 million platelets per milliliter. So, the platelet content in it exceeds the physiological norm by five times. It is believed that such a high concentration of platelets in the affected tissues provides a stimulating effect by triggering cytokine reactions and isolating many growth factors. These cytokines are leading agents in the processes of cell differentiation, proliferation and regeneration. Thus, in the pathological focus there is an accelerated restoration of damaged tissues, inflammatory processes are reduced, and trophism in the lesion focus is improved directly. This technique is safe (autogenous blood is used) and physiological as it does not cause any toxic, allergic reactions and is well tolerated by all animals [33].

In a number of works devoted to the treatment of degenerative diseases of bones and joints, plateletrich plasma, containing various growth factors, is considered to be an agent able to control the biological potential of the body [34, 35, 36, 37, 38].

It is still difficult to say which element, hydroxyapatite or PRP, plays a larger role in the 
process of differentiation of chondrogenic cells and articular cartilage regeneration.

Further studies will answer questions about the mechanical strength of the newly formed articular surface and its possible "crushing" in the long term. The histological features of the structure of the articular cartilage in the longterm follow-up will allow solving many issues of improving the technology of arthroplasty of the damaged joint.

\section{CONCLUSION}

Thus, the study showed that when an articular surface defect in the canine femoral condyles was filled with an elastic biodegradable hydroxyapatitecoated polycaprolactone implant combined with the introduction of platelet-rich autogenous plasma into the defect, restoration of the articular surface congruence and mosaic replacement of the implanted area with hyaline-like cartilage were noted after two months, while in the subchondral bone region a new

\section{cancellous bone was formed.}

The results obtained may be promising in terms of the possibility of prolonging the functional ability of joints in patients with articular cartilage defects, and in the future (after longer experimental and clinical observations) may offer a new universal method for filling articular defects of various etiologies with the possibility of their biomechanical and organotypical restoration.

\section{REFERENCES}

1. Peterson L., Brittberg M., Kiviranta I., Akerlund E.L., Lindahl A. Autologous chondrocyte transplantation. Biomechanics and longterm durability. Am. J. Sports Med., 2002, vol.30, no. 1, pp. 2-12. DOI: 10.1177/03635465020300011601.

2. Bert J.M., Maschka K. The arthroscopic treatment of unicompartmental gonarthrosis: a five-year follow-up study of abrasion arthroplasty plus arthroscopic debridement and arthroscopic debridement alone. Arthroscopy, 1989, vol. 5, no. 1, pp. 25-32. DOI: 10.1016/0749-8063(89)90086-8.

3. Fitzpatrick P.L., Morgan D.A. Fresh osteochondral allografts: a 6-10-year review. Aust. N. Z. J. Surg., 1998, vol. 68, no. 8, pp. 573579. DOI: 10.1111/j.1445-2197.1998.tb02103.x.

4. Winslow A.J., Cole B.J. Cartilage restoration, part 1: basic science, historical perspective, patient evaluation, and treatment options. Am. J. Sports Med., 2005, vol. 33, no. 2, pp. 295-306. DOI: 10.1177/0363546504273510.

5. Pridie K.H. A method of resurfacing knee joints. J. Bone Joint Surg. Br., 1959, vol. 41, pp. 618-619.

6. Steadman J.R., Rodkey W.G., Rodrigo J.J. Microfracture: surgical technique and rehabilitation to treat chondral defects. Clin. Orthop. Relat. Res., 2001, no. 391 Suppl., pp. S362-S369. DOI: 10.1097/00003086-200110001-00033.

7. Buryanov O.A. Sobolevsky Yu.L., Kvasha V.P. Kistkovomozkova stimuliatsiia (mikrofrakturizatsiia) u kompleksnomu likuvanni khvorikh z ushkodzhenniami khriashcha kolinnogo sugloba [Bone marrow stimulation (microfracturization) in the complex treatment of patients with cartilage injuries of the knee joint]. Ortopediia, Travmatologiia i Protezirovanie, 2008, no. 3, pp. 23-27. (in Ukrainian)

8. Outerbridge H.K., Outerbridge A.R., Outerbridge R.E. The use of a lateral patellar autologous graft for the repair of a large osteochondral defect in the knee. J. Bone Joint Surg. Am., 1995, vol. 77, no. 1, pp. 65-72. DOI: 10.2106/00004623-199501000-00009.

9. Lee C.R., Grodzinsky A.J., Hsu H.P., Spector M. Effects of a cultured autologous chondrocyte-seeded type II collagen scaffold on the healing of a chondral defect in a canine model. J. Orthop. Res., 2003, vol. 21, no. 2, pp. 272-281. DOI: 10.1016/S07360266(02)00153-5.

10.Bae D.K., Yoon K.H., Song S.J. Cartilage healing after microfracture in osteoarthritic knees. Arthroscopy, 2006, vol. 22, no. 4, pp. 367-374. DOI:10.1016/j.arthro.2006.01.015.

11. Steinwachs MR, Kreuz PC, Guhlke-Steinwachs U, Niemeyer P. Current treatment for cartilage damage in the patellofemoral joint. Orthopade, 2008, vol. 37, no. 9, pp.841-847. DOI:10.1007/s00132-008-1290-9.

12. Grande D.A., Halberstadt C., Naughton G., Schwartz R., Manji R. Evaluation of matrix scaffolds for tissue engineering of articular cartilage grafts. J. Biomed. Mater. Res., 1997, vol. 34, no. 2, pp. 211-220. DOI: 10.1002/(sici)1097-4636(199702)34:2<211::aid-jbm10>3.0.co;2-l.

13.Becher C., Huber R., Thermann H., Paessler H.H., Skrbensky G. Effects of a contoured articular prosthetic device on tibiofemoral peak contact pressure: a biomechanical study. Knee Surg. Sports Traumatol. Arthrosc., 2008, vol. 16, no. 1, pp. 56-63. DOI: 10.1007/ s00167-007-0416-7.

14.Miniaci A. A metal cap solution for focal cartilage deficiency. 25 th Annual Current Concepts in Joint Replacement Winter Meeting. Orlando, 2008, paper No 74 .

15.Pavlova V.N., Kopeva T.N., Slutskii L.I., Pavlov G.G. Khriashch [Cartilage]. M., Meditsina, 1988, 320 p. (in Russian)

16.Mankin H.J. The response of articular cartilage to mechanical injury. J. Bone Joint Surg. Am., 1982, vol. 64, no. 3, pp. 460-466.

17.Tsurko V.V. Osteoartroz: problema geriatrii [Osteoarthrosis: geriatrics problem]. M., Niudiamed, 2004, 136 p. (in Russian)

18.Stupina T.A., Shchudlo M.M. Sustavnoi khriashch: izmeneniia pri chreskostnom distraktsionnom osteosinteze, fiziologicheskaia i reparativnaia regeneratsiia (obzor literatury) [The articular cartilage: changes for transosseous distraction osteosynthesis, physiological and reparative regeneration (Review of literature)]. Genij Ortopedii, 2012, no. 4, pp. 137-141. (in Russian)

19.Müller B, Kohn D. Indication for and implementing of subchondral drilling according to Pridie. Orthopade, 1999, vol. 28, no.1, pp. 4-10. DOI: $10.1007 / \mathrm{s} 001320050315$.

20.Makushin V.D., Chegurov O.K., Sazonova N.V., Buravtsov P.P., Bunov V.S., Kamshilov B.V. Gonartroz: alternativnye metody operativnogo lecheniia [Gonarthrosis: alternative methods of surgical treatment]. Makushin V.D., editor. Kurgan, Zaurale, 2010, 625 p. (in Russian)

21.Eismont O.L., Pashkevich L.A., Maliuk B.V., Golutvina N.O., Borisov A.V., Bukach D.V. Vliianie perforatsii osteokhondralnoi plastinki na regeneratsiiu povrezhdennogo sustavnogo khriashcha $v$ eksperimente [The effect of osteochondral plate perforation on the damaged articular cartilage regeneration experimentally]. Vestsy Natsyianalnai Akademii Navuk Belarusi. Seryia medytsynskikh navuk, 2010, no. 3, pp. 32-37. (in Russian) 
22.Steadman J.R., Rodkey W.G., Singleton S.B., Briggs K.K. Microfracture technique for full-thickness chondral defects: Technique and clinical results. Operative Techniques in Orthopaedics, 1997, vol. 7, no. 4, pp. 300-304. DOI: 10.1016/S1048-6666(97)80033-X.

23.Chen H., Sun J., Hoemann C.D., Lascau-Coman V., Ouyang W., McKee M.D., Shive M.S., Buschmann M.D. Drilling and microfracture 1 ead to different bone structure and necrosis during bone-marrow stimulation for cartilage repair. J. Orthop. Res., 2009, vol. 27, no. 11, pp. 1432-1438. DOI:10.1002/jor.20905.

24.Jacobi M., Villa V., Magnussen R.A., Neyret P. MACI - a new era? Sports Med. Arthrosc. Rehabil. Ther. Technol., 2011, vol. 3, no. 1, pp. 10. DOI: 10.1186/1758-2555-3-10.

25.Hangody L., Kish G., Kárpáti Z., Udvarhelyi I., Szigeti I., Bély M. Mosaicplasty for the treatment of articular cartilage defects: application in clinical practice. Orthopedics, 1998, vol. 21, no. 7, pp. 751-756.

26.Hangody L., Füles P. Autologous osteochondral mosaicplasty for the treatment of full-thickness defects of weight-bearing joints: ten years of experimental and clinical experience. J. Bone Joint Surg. Am., 2003, vol. 85-A, no. Suppl. 2, pp. 25-32. DOI: 10.2106/00004623-200300002-00004.

27.Lamplot J.D., K.A. Schafer, M.J. Matava, Treatment of Failed Articular Cartilage Reconstructive Procedures of the Knee: A Systematic Review. Orthop. J. Sports Med., 2018, vol. 6, no. 3, pp. 2325967118761871. DOI: 10.1177/2325967118761871.

28.Brittberg M., Lindahl A., Nilsson A., Ohlsson C., Isaksson O., Peterson L. Treatment of deep cartilage defects in the knee with autologous chondrocyte transplantation. N. Engl. J. Med., 1994, vol. 331, no. 14, pp. 889-895. DOI: 10.1056/NEJM199410063311401.

29.Batty L., Dance S., Bajaj S., Cole B.J. Autologous chondrocyte implantation: an overview of technique and outcomes. ANZ J. Surg., 2011, vol. 81, no. 1-2, pp. 18-25. DOI: 10.1111/j.1445-2197.2010.05495.x.

30.Peterson L., Menche D., Grande D., Puman M. Chondrocyte transplantation: an experimental model in the rabbit. Transactions from the 30 th Annual Meeting Orthopaedic Research Society, Atlanta, 7-9 February, 1984. P. 218.

31.Browne J.E., Anderson A.F., Arciero R., Mandelbaum B., Moseley J.B. Jr., Micheli L.J., Fu F., Erggelet C. Clinical outcome of autologous chondrocyte implantation at 5 years in US subjects. Clin. Orthop. Relat. Res., 2005, no. 436, pp. $237-245$. DOI:10.1097/00003086-200507000-00036.

32.Shilkin A.G., Voitekha M.A., Pavlova T.N., Novikova K.A. Primenenie plazmy, obogashchennoi trombotsitami, v veterinarnoi oftalmologii [The use of platelet-rich plasma in veterinary ophthalmology]. Rossiiskii Veterinarnyi Zhurnal, 2017, no. 2, pp. 6-9. (in Russian)

33.Shirokova L.Iu., Noskov S.M., Bakhtiarova T.I., Snigireva A.V., Noskova T.S. Lokalnaia terapiia gonartroza autologichnoi obogashchennoi trombotsitami plazmoi [Local therapy of gonarthrosis with autologous platelet-rich plasma]. Sovremennye Tekhnologii v Meditsine, 2012, no. 1, pp. 97-100. (in Russian)

34.Shirokova K., Noskov S., Shirokova L. Comparison of clinical efficacy of platelet-rich plasma and autologous conditioned serum treatment in patients with osteoarthritis of the knee. Osteoarthritis Cartilage, 2017, vol. 25, no. Suppl. 1, pp. S438. DOI: 10.1016/j. joca.2017.02.756.

35.Filardo G., Kon E., Roffi A., Di Matteo B., Merli M.L., Marcacci M. Platelet-rich plasma: why intra-articular? A systematic review of preclinical studies and clinical evidence on PRP for joint degeneration. Knee Surg. Sports Traumatol. Arthrosc., 2015, vol. 23, no. 9, pp. 2459-2474. DOI: 10.1007/s00167-013-2743-1.

36.Korytkin A.A., Zykin A.A., Zakharova D.V., Novikova Ia.S. Primenenie obogashchennoi trombotsitami plazmy pri zameshchenii ochaga avaskuliarnogo nekroza golovki bedrennoi kosti allotransplantatami [The use of platelet-rich plasma when replacing the focus of the femoral head avascular necrosis with allografts]. Travmatologiia i Ortopediia Rossii, 2018, vol. 24, no. 1, pp. 115-122. (in Russian)

37. Osawa A., Maruyama Y., Kaneko K. An examination of growth factor levels in platelet-rich plasma and correlations with age, gender, platelet count, and DHEAS. Osteoarthritis Cartilage, 2015, vol. 23, no. Suppl. 2, pp. A400. DOI: 10.1016/j.joca.2015.02.738.

Received: 17.03.2020

\section{Information about the authors:}

1. Arnold V. Popkov, M.D., Ph.D., Professor, Ilizarov National Medical Research Centre for Traumatology and Orthopedics, Kurgan, Russian Federation, Email: apopkov.46@mail.ru

2.Dmitry A. Popkov, M.D., Ph.D., Professor of RAS, correspondent member French Academy of Medical Sciences, Ilizarov National Medical Research Centre for Traumatology and Orthopedics, Kurgan, Russian Federation, Email: dpopkov@mail.ru

3. Andrei E. Kobyzev, M.D., Ph.D.,

Ilizarov National Medical Research Centre for Traumatology and Orthopedics, Kurgan, Russian Federation

4. Elena N. Gorbach, Ph.D. of Biological Sciences,

Ilizarov National Medical Research Centre for Traumatology and Orthopedics, Kurgan, Russian Federation, Email: gorbach.e@mail.ru

5. Natalia A. Kononovich, Ph.D. of Veterinary Sciences,

Ilizarov National Medical Research Centre for Traumatology and Orthopedics, Kurgan, Russian Federation, Email: n.a.kononovich@mail.ru

6. Evgeniy S. Gorbach, Ilizarov National Medical Research Centre for Traumatology and Orthopedics, Kurgan, Russian Federation, Email: gorbach.evg@mail.ru 